\title{
Serological Survey of Neospora caninum Infection in Cattle Herds From Western Romania
}

\begin{abstract}
Kálmán Imre, Sorin Morariu*, Marius S. Ilie*, Mirela Imre*, Nicola Ferrari†, Claudio Genchi†, and Gheorghe Dărăbuș ${ }^{\star}+$, Department of Food Hygiene and Veterinary Public Health, Faculty of Veterinary Medicine, Banat University of Agricultural Sciences and Veterinary Medicine Timişoara, Calea Aradului nr. 119, 300645 Timişoara, Romania; *Department of Parasitology and Parasitic Diseases, Faculty of Veterinary Medicine, Banat University of Agricultural Sciences and Veterinary Medicine Timişoara, Calea Aradului nr. 119, 300645 Timişoara, Romania; †Dipartimento di Patologia Animale, Igiene e Sanità Pubblica Veterinaria, Sezione di Patologia Generale e Parasitologia, Università degli Studi di Milano, Milano, Italy 20133; łTo whom correspondence should be addressed.e-mail: kalman_imre27@yahoo.com; gheorghe.darabus@fmvt.ro
\end{abstract}

ABSTRACT: Serum samples from 376 randomly selected adult cattle, from 25 farms located in 3 counties (Arad, Bihor, and Timiş) from western Romania, were sampled for Neospora caninum antibodies using a commercial ELISA-kit. Seroprevalence values and risk factors for neosporosis (cow age, breed, herd size, farming system, previous abortion, and number of farm dogs) were examined using a generalized linear mixed model with a binomial distribution. Overall, the seroprevalence of $N$. caninum was $27.7 \%$ (104/376) with a prevalence of $27.9 \%$ (24/86) in Arad, $26.9 \%$ (25/93) in Bihor, and 27.9\% (55/197) in Timiş. Of 25 cattle herds, 23 were seropositive with a prevalence ranging from 10.0 to $52.2 \%$. No correlation was found between $N$. caninum seropositivity and age, breed, herd size, breeding system, and previous abortion. The number of farm dogs was the only factor $\left(P_{\text {Wald }}=0.03\right)$ positively associated with seroprevalence in cows and can be considered the risk factor in the acquiring of infection. The present work is the first regarding serological evidence of $N$. caninum infection in cattle from western Romania.

Neospora caninum is a cosmopolitan coccidian parasite of cattle and one of the major causes of abortion, neonatal mortality, and reduced milk production (Hernandez et al., 2001; Dubey and Schares, 2011). In domestic dogs (Canis lupus familiaris), which serve as the definitive hosts for $N$. caninum along with gray wolfs (Canis lupus) and coyotes (Canis latrans), neuromuscular disorders have been reported frequently (Dubey et al., 2007; Eiras et al., 2011). Endogenous transplacental transmission (vertical transmission) is probably the most important route of infection in cattle, although the parasite can be acquired through the ingestion of oocysts shed from definitive hosts (horizontal transmission) (Trees and Williams, 2005; Dubey and Schares, 2011).

Several studies have investigated the seroprevalence of $N$. caninum infection in adult cattle worldwide and the data have varied significantly depending on the study design, specificity, and sensitivity of the serologic techniques used as well as on the tested herd (Dubey et al., 2007). Currently, the most frequently used methods for screening cattle include enzyme-linked immunosorbent assay (ELISA), indirect immunofluorescent antibody tests, immunoblot analysis, and an $N$. caninum-agglutination test (Conraths and Gottstein, 2007). These tools are very useful in the implementation of more-effective control strategies in cattle herds.

A previous serosurvey of bovine neosporosis in Romania was limited to the center and northwest of the country and was carried out on cows with a history of reproduction problems (Gavrea and Cozma, 2010). Additionally, molecular identification of $N$. caninum infection in aborted bovine fetuses has been reported in the same region (Şuteu et al., 2010). The aim of the present study was to provide data on the seroprevalence of $N$. caninum in cattle herds in western Romania and to assess the possible risk factors associated with the infection.

The survey was carried out using a non-probabilistic sampling procedure of convenience in 25 dairy cow farms in 3 counties from western Romania; Arad $(\mathrm{n}=7)$, Bihor $(\mathrm{n}=6)$, and Timiş $(\mathrm{n}=12)$. From January 2009 to June 2011, 376 blood samples $(5 \mathrm{ml})$ were collected by jugular venipuncture. Data regarding age, breed (203 Holstein Friesian dairy cows and 176 autochthonous dairy cow Sură de Stepă Transilvăneană $\times$ Simmental), herd size, farming system (146 from grazing systems and 230 from industrial farming), abortion problems (133 yes and 243 no), and the number of dogs per farm (range 0-10) were recorded at the time of blood sampling. Eighty-nine cows were aged from 2 to $\leq 4 \mathrm{yr}, 120$ were $>4$

DOI: 10.1645/GE-3023.1 to $\leq 6 \mathrm{yr}, 72$ were $>6$ to $\leq 8 \mathrm{yr}$, and 95 were $>8 \mathrm{yr}$. The occurrence of abortion was not used as a criterion to select the sampled animals.

Sera were obtained by centrifugation at $1,200 \mathrm{~g}$ for $10 \mathrm{~min}$ and frozen at $-20 \mathrm{C}$ until analysis. Sera were assayed for anti- $N$. caninum antibodies using a commercially available competitive ELISA-kit (BIO K 218, Bio-X Diagnostics, Jemelle, Belgium). The 96-well microtitration plates of the test were coated with whole SRS2 (p38) Neospora caninum/Escherichia coli recombinant antigen (protein). The ELISA procedure was performed according to the manufacturer's recommendations.

To identify risk factors for cows being seropositive to $N$. caninum, a generalized linear mixed model with a binomial distribution was fitted. The relationship of the serological status of cows to $N$. caninum was compared with the following explanatory variables: Cow age, breed, herd size, farming system, previous abortion, and number of dogs on the farm. A maximal model with up to all second-order interaction between the explanatory variables was fitted. Variables that did not significantly contribute to the model explanation were assessed and dropped through a deletion test until the minimal adequate model was obtained (Crawley, 2007). To overcome the autocorrelation due to the nested structure of the sampling from common farms, the latter was included as a random factor into the model.

The results are shown in Table I. Overall, of 376 sampled sera, 104 (27.7\%) were positive for $N$. caninum. Antibodies to $N$. caninum were found in all 3 counties with a herd seroprevalence of $100 \%$ (7/7) in Arad, $83.3 \%$ (5/6) in Bihor, and $91.6 \%$ (11/12) in Timiş. Of the 25 sampled herds, $23(92 \%)$ were positive with a seroprevalence ranging between 10.0 and $52.2 \%$.

The seroprevalence of $N$. caninum in the 4 age groups ranged from $23.3 \%$ ( $>4$ to $\leq 6 \mathrm{yr}$ ) to $31.6 \%$ ( $>8 \mathrm{yr}$ ) (Table I); $25.0 \%(50 / 200)$ of purebred cows and $30.6 \%(54 / 176)$ of crossbreed cows were positive to $N$. caninum ELISA. The seroprevalence ranged from $20.0 \%$ in herds of 200 300 cows to $30.6 \%$ in small herds ( $<100$ cows). The percent of seropositive cows in grazing systems was $30.1 \%$ (44/146) compared to $26.1 \%$ (60/230) in the industrial systems. The seroprevalence of cows with a previous history of abortion was $29.3 \%(39 / 133)$ and $26.7 \%$ (65/243) in nonaborting cows. The seroprevalence was $30.8 \%$ (91/295) in cows from farms with dogs and 16\% (13/81) in cows from farms with no dogs.

This is the first study that reports serological evidence of $N$. caninum infection in cattle herds from western Romania. From an epidemiological perspective, our results show a widespread occurrence of $N$. caninum infection in the bovine population from this region. The seroprevalence (27.7\%) in 3 counties (Arad, Bihor, and Timiş) was lower, however, than that previously reported in cattle with reproductive problems from dairy farms in central and northern regions of the country (55.9\%; Gavrea and Cozma, 2010). Compared to several other European countries, our seroprevalence was higher than that reported in Slovakia (20.1\%; Reiterová et al., 2009) and Hungary (2.5\%; Hornok et al., 2006), similar to that found in the northwest of Spain (23.2\%; Eiras et al., 2011) but lower than that reported in Italy (32.0\%; Rinaldi et al., 2007) and Turkey (46.5\%; Kul et al., 2009).

The statistical analysis showed that the age of cows, breed, herd size, farming system, and previous abortion did not significantly influence $N$. caninum seroprevalence $\left(P_{\text {Wald }}>0.05\right)$. However, the number of dogs per farm was positively associated with $N$. caninum seroprevalence in cows $\left(P_{\text {Wald }}=0.043\right)$, as previously observed by Paré et al. (1998) and Dijkstra et al. (2002) and, more recently, by Schares et al. (2004) and Hobson et al. (2005), although this contradicts several studies that did not find an association between farm dogs and bovine neosporosis (Rodriguez et al., 2002; Fischer et al., 2003). The lack of association between previous 
TABLE I. Neospora caninum antibodies in cattle in western Romania according to individual animal and epidemiological data.

\begin{tabular}{|c|c|c|c|}
\hline $\begin{array}{l}\text { Individual animal and } \\
\text { epidemiological data }\end{array}$ & $\begin{array}{l}\text { No. of sampled } \\
\text { animals }\end{array}$ & $\begin{array}{l}\text { No. of positive } \\
\text { samples }\end{array}$ & $\begin{array}{l}\text { Prevalence } \\
(\%)\end{array}$ \\
\hline \multicolumn{4}{|l|}{ Counties } \\
\hline Arad & 86 & 24 & 27.9 \\
\hline Bihor & 93 & 25 & 26.9 \\
\hline Timiş & 197 & 55 & 27.9 \\
\hline \multicolumn{4}{|l|}{ Age } \\
\hline 2 to $\leq 4 \mathrm{yr}$ & 89 & 28 & 31.5 \\
\hline$>4$ to $\leq 6 \mathrm{yr}$ & 120 & 28 & 23.3 \\
\hline$>6$ to $\leq 8 \mathrm{yr}$ & 72 & 18 & 25.0 \\
\hline$>8 \mathrm{yr}$ & 95 & 30 & 31.6 \\
\hline \multicolumn{4}{|l|}{ Breed } \\
\hline Purebreed & 200 & 50 & 25.0 \\
\hline Crossbreed & 176 & 54 & 30.6 \\
\hline \multicolumn{4}{|l|}{ Herd size } \\
\hline$<100$ & 85 & 26 & 30.6 \\
\hline $100-200$ & 174 & 51 & 29.3 \\
\hline $201-300$ & 45 & 9 & 20.0 \\
\hline $301-600$ & 72 & 18 & 25.0 \\
\hline \multicolumn{4}{|l|}{ Farming system } \\
\hline Grazing & 146 & 44 & 30.1 \\
\hline Industrial & 230 & 60 & 26.1 \\
\hline \multicolumn{4}{|l|}{ Previous abortion } \\
\hline Yes & 133 & 39 & 29.3 \\
\hline No & 243 & 65 & 26.7 \\
\hline \multicolumn{4}{|l|}{ Farm dogs } \\
\hline Yes & 295 & 91 & 30.8 \\
\hline No & 81 & 13 & 16.0 \\
\hline
\end{tabular}

abortions and seroprevalence in cows is not surprising considering that a number of factors can influence the abortion in dams (Schares et al., 2004), not least the genetic and biological diversity of field isolates (Schock et al., 2001) and the dam's immunity (Innes et al., 2001). Moreover, only a proportion of infected cows abort (Williams et al., 2000). In contrast, the results of other investigations carried out in Brazil (Corbellini et al., 2002), Japan (Koiwai et al., 2005), and Slovakia (Reiterová et al. 2009) showed a higher seropositivity of antibodies to N. caninum in aborting cows then in non-aborting animals. Also, the finding in our study of no significant association between the seroprevalence and farming system is in contrast with findings of Wang et al. (2010), who observed a significantly higher seroprevalence in grazing dairy cattle than that in cattle using confined feeding $(28.6 \%$ vs. $10.7 \%)$.

No significant difference $\left(P_{\text {Wald }}>0.05\right)$ was found between the seroprevalence of $N$. caninum antibodies associated with the breed of the animals. Several studies have shown that dairy cattle are more susceptible to N. caninum than are beef cattle (Bartels et al., 2006; Hornok et al., 2006; Rinaldi et al. 2007), and vice versa (Eiras et al. 2011), but breed-related susceptibility to infection was not demonstrated; in addition, the role of farm dogs was not investigated in these studies.

In conclusion, this study shows that there is a close association between $N$. caninum seropositivity and the number of dogs on cattle farms. Therefore, in this region also, control should be focused mainly on avoiding contact between cattle and natural definitive hosts or protection of cattle food and drinking water from contamination by dog feces with sporulated oocysts. Likewise, preventing the consumption of infected aborted products (stillborn calves, fetuses, and fetal membranes) by dogs, and continuous serological follow-up of the cattle herds, must be an integrated part of the control.

This study was carried out during the project "Postdoctoral School of Agriculture and Veterinary Medicine Posdru/89/1.5/S/62371," co-financed by the European Social Fund through the Sectorial Operational Programme for the Human Resources Development 2007-2013. We would like to thanks farmers and veterinarians for their assistance in the collection of samples.

\section{LITERATURE CITED}

Bartels, C. J., J. L. Arnaiz-Seco, A. Ruiz-Santa-Quitera, C. Buörkman, J. Frössling, D. Von Blunmröder, F. J. Conraths, G. Schares, C. Van MaAnen, W. Wouda, ET AL. 2006. Supranational comparison of Neospora caninum seroprevalence in cattle in Germany, The Netherlands, Spain and Sweden. Veterinary Parasitology 137: 17-27.

Conraths, F. J., And B. Gottstein. 2007. Aetiological diagnosis, neosporosis. In Protozoal abortion in farm ruminants: Guidelines for diagnosis and control, L. M. Orthega-Mora, B. Gottstein, F. J. Conraths, and F. J. Buxton (eds.). CAB International, Wallingford, U.K., p. $42-122$.

Corbellini, L. G., D. Driemeier, C. F. E. Cruz, L. F. P. Gondim, and V. WALD. 2002. Neosporosis as a cause of abortion in dairy cattle in Rio Grande do Sul, southern Brazil. Veterinary Parasitology 103: 195-202.

Crawley, M. J. 2007. The R book. John Wiley and Sons Ltd., Chichester, U.K., 950 p.

Dijkstra, T., H. W. Barkema, M. Eysker, J. W. Hesselink, and W. WoudA. 2002. Natural transmission routes of Neospora caninum between farm dogs and cattle. Veterinary Parasitology 105: 99-104.

Dubey, J. P., AND G. Schares. 2011. Neosporosis in animals-The last five years. Veterinary Parasitology 180: 90-108.

- and L. M. Ortega-Mora. 2007. Epidemiology and control of neosporosis and Neospora caninum. Clinical Microbiology Reviews 20: 323-367.

Eiras, C., I. Arnaiz, G. Álvarez-García, L. M. Ortega-Mora, M. L. Sanjuánl, E. Yus, and F. J. Diéguez. 2011. Neospora caninum seroprevalence in dairy and beef cattle from the northwest region of Spain, Galicia. Preventive Veterinary Medicine 98: 128-132.

Fischer, I., K. Furrer, L. Aufdige, A. Fritsche, T. Giger, B. Gottstein, AND H. SAGer. 2003. Von der Bedeutung der bovinen neosporose beim abortgeschehen in der Schweiz. Schweizer Archiv für Tierheilkunde 145: 114-123.

Gavrea, R. R., AND V. Cozma. 2010. Seroprevalence of Neospora caninum in cows with reproductive failure in center and northwest of Romania. Scientia Parasitologica 11: 67-70.

Hernandez, J., C. Risco, and A. Donovan. 2001. Association between exposure to Neospora caninum and milk production in dairy cows. Journal of the American Veterinary Medical Association 219: 632-635.

Hobson, J. C., T. F. Duffield, D. Kelton, K. Lissmore, S. K. Hietala, K. E. Leslie, B. McEwen, and A. S. Peregrine. 2005. Risk factors associated with Neospora caninum abortion in Ontario Holstein dairy herds. Veterinary Parasitology 127: 177-188.

Hornok, S., R. Edelhofer, and I. Hajtós. 2006. Seroprevalence of neosporosis in beef and dairy cattle breeds in northeast Hungary. Acta Veterinaria Hungarica 54: 485-491.

Innes, E. A., S. E. Wright, S. Maley, A. Rae, A. Schock, E. Kirvar, P. Bartley, C. Hamilton, I. M. Carey, and D. Buxton. 2001. Protection against vertical transmission in bovine neosporosis. International Journal for Parasitology 31: 1523-1534.

Koiwai, M., T. Hamaoka, M. Haritani, S. Shimizu, and K. Kimura. 2005. Proportion of abortions due to neosporosis among dairy cattle in Japan. Journal of Veterinary Medical Science 67: 1173-1175.

Kul, O., N. Kabakci, K. Yildiz, N. Ocal, H. Kalender, and N. A. ILKME. 2009. Neospora caninum associated with epidemic abortions in dairy cattle: The first clinical neosporosis report in Turkey. Veterinary Parasitology 159: 69-72.

Paré, J., G. Fecteau, M. Fortin, and G. Marsolais. 1998. Seroepidemiologic study of Neospora caninum in dairy herds. Journal of the American Veterinary Medical Association 213: 1595-1598.

Reiterová, K., S. Špilovska, D. Antalová, and P. Dubinský. 2009. Neospora caninum, potential cause of abortions in dairy cows: The current serological follow-up in Slovakia. Veterinary Parasitology 159: $1-6$.

Rinaldi, L., F. Pacelli, G. Iovane, U. Pagnini, V. Veneziano, G. Fusco, And G. CRingoli. 2007. Survey of Neospora caninum and bovine herpes virus 1 coinfection in cattle. Parasitology Research 100: 359 364. 
Rodriguez, I., L. Choromanski, S. J. Rodgers, and D. Weinstock. 2002. Survey of Neospora caninum antibodies in dairy and beef cattle from five regions of the United States. Veterinary Therapeutics 3: 396-401.

Schares, G., A. Bärwald, C. Staubach, M. Ziller, D. Klöss, R. Schroder, R. Labohm, K. Dräger, W. Fasen, R. G. Hess, et al. 2004. Potential risk factors for bovine Neospora caninum infection in Germany are not under the control of the farmers. Parasitology 129: 301-309.

Schock, A., E. A. Innes, I. Yamane, S. M. Latham, and J. M. Wastling. 2001. Genetic and biological diversity among isolates of Neospora caninum. Veterinary Parasitology 123: 13-23.

Șuteu, O., A. Titilincu, D. Modrý, A. Mihalca, V. Mircean, and V. Cozma. 2010. First identification of Neospora caninum by PCR in aborted bovine foetuses in Romania. Parasitology Research 106: 719722.

Trees, A. J., And D. J. L. Williams. 2005. Endogenous and exogenous transplacental infection in Neospora caninum and Toxoplasma gondii. Trends in Parasitology 21: 558-561.

Wang, C., Y. Wang, X. Zou, Y. Zhai, J. GaO, M. Hou, and X. Q. Zhu. 2010. Seroprevalence of Neospora caninum infection in dairy cattle in northeastern China. Journal of Parasitology 96: 451-452.

Williams, D. J. L., C. S. Guy, J. W. McGarry, F. Guy, L. Tasker, R. F. Smith, K. MacEachern, P. J. Cripps, D. F. Kelly, and A. J. Trees. 2000. Neospora caninum associated with abortion in cattle: The time of experimentally induced parasitemia during gestation determines foetal survival. Parasitology 121: 347-358. 